\title{
THE CONCEPT OF METHOD FOR DETERMINING THE MINIMUM LEVEL OF AIRPORT BUSINESS CONTINUITY
}

\section{KONCEPCJA METODY WYZNACZANIA MINIMALNEGO POZIOMU CIĄGLOŚCI DZIALANIA PORTU LOTNICZEGO}

\author{
Michał Kozlowski \\ Warsaw University of Technology \\ Politechnika Warszawska \\ m.kozlowski@wt.pw.edu.pl
}

\begin{abstract}
The paper presents the problem of determining the minimum acceptable level of products and services of airport business continuity. Conducted a study of legal requirements and operational needs. Characterized components of BCMS (ISO 22301). Determined the relationship between measures of the reliability and capacity in the airport BCMS. On this basis, presented a concept of use the reliability gamma-percent resource measure and RCM methods in the airport BCMS.
\end{abstract}

Keywords: airport, minimum acceptable level of products and services of airport business continuity, reliability gamma-percent resource measure, crisis management

Streszczenie: Tematem publikacji jest problem wyznaczania minimalnego poziomu ciagłości działania portu lotniczego. Przeprowadzono studium wymagań prawnych i potrzeb operacyjnych. Scharakteryzowano komponenty BCMS (ISO 22301). Określono relacje pomiędzy miarami niezawodności i przepustowości portu lotniczego w BCMS. Na tej podstawie przedstawiono koncepcje zastosowania gamma-procentowego zasobu pracy $i$ metod RCM $w$ zarzadzaniu ciagłościa działania portu lotniczego.

Stowa kluczowe: port lotniczy, minimalny poziom ciagłości działania, gammaprocentowy zasób pracy, zarządzanie kryzysowe 
The concept of method for determining the minimum level of airport business continuity

Koncepcja metody wyznaczania minimalnego poziomu ciaglości działania portu lotniczego

\section{THS CONCEPT OF METHOD FOR DETERMINING THE MINIMUM LEVEL OF AIRPORT BUSINESS CONTINUITY}

\section{Introduction}

The aim of the operation of the airport is handling aircraft operations in the aerodrome traffic and commercial air transport. The airport operational include:

- aircraft operations (departures and arrivals);

- aircraft ground handling;

- passenger, baggage, cargo and mail ground handling;

- airport infrastructure maintenance;

- safety management;

- security against unlawful acts.

These processes are subject to the influence of numerous (in the majority of cases, random) factors, the sources of which include: environment, the failure of infrastructure elements, human factors, air traffic flow management.

Laws [12] require all entities (airport operators, air carriers, ground handling agents, air traffic management) and state services (border guards, police, customs) priority responsibilities to ensure the security and continuity and regularity of air traffic and transport. Legally defined safety objectives are achieved in particular by maintaining continuous compliance with regulatory specifications [2, 3] and the implementation required by law [15] Security Management System - SMS. The objectives of the continuity of the operation are achieved in particular by implementation the Business Continuity Management System - BCMS [10].

\section{The issue of airport business continuity}

Business continuity is a capability of the organization to continue delivery of products or services at acceptable predefined levels following disruptive incident [10]. This normative definition indicates that the issue of airport business continuity should be considered in the aspects of:

- objectives and requirements of the airport operation;

- volume of servicing air traffic and transport;

- interrupting incidents.

In relation to the safety, continuity and regularity objectives and requirements concerning airport operation of the airport, it should be noted that the airport infrastructure belongs to the state critical infrastructure (ie. systems and their constituent related functional objects, including building structures, equipment, installations, services essential to the security of the state and its citizens and to ensure the efficient functioning of public administration and the institutions and entrepreneurs (...) [13]). Law acts define specific requirements and legal obligations $[7,8,13]$ for critical infrastructure protection (ie. all activities aimed at ensuring the functionality, continuity and integrity of critical infrastructures in order to prevent threats, risks or weaknesses and limitations and neutralize their effects and the rapid restoration of infrastructure in the event of failure, attacks and 
other incidents affecting its function. [13]). One of the legal requirement is to develop and maintain readiness to implement the Critical Infrastructure Protection Programme [7], in the scope of which are defined among others:

- objectives and priorities;

- improving conditions;

- crisis management procedures;

- restore critical infrastructure procedures;

- results of hazard identification;

- forecasts for critical infrastructure operators;

- expected interruptions;

- needs to support critical infrastructure operators.

The Critical Infrastructure Protection Programme must provide three options in proceeding [8], ie.:

- emergency situation;

- ensuring continuity of operation;

- restoring critical infrastructure.

Some special requirements [2] is to established contingency arrangements to deal with the possibility of apron congestion due to a large influx of diverted aircraft (eg. in the case of adverse fly meteorological conditions, occurrence of an act of unlawful interference, volcanic eruption, disruption of air traffic flow, or other crisis and emergencies). Warning arrangements should be made to alert operators to any approaching saturation of apron or terminal facilities.

The volume of the air traffic and transport servicing at airport should be examined with the use some measures of airport capacity [5] and the level of actual airport capacity saturation.

Measures of interrupt or reduce the level of airport operation process will be expressed as a volume of flight operations delay and the number of canceled or diverted flights [9].

Disruption and interruption incidents at airport may have different causes and likelihood of occurrence. The most important are the consequences and their impact on the airport operation processes, taking into account two types of consequences, ie.:

- decrease airport capacity (and aircraft operations, ground handling punctuality);

- increase demand for air traffic services and ground handling.

Another specific airport risks, are the epidemic risks, for which the airports are so-called "Points of entry".

In each of the highlighted cases will occur delays and limitations in air traffic services and ground handling, which, on a so-called "Domino effect" will be able to grow and expand the size of losses and will be able to produce another, different kind of hazards.

\section{ISO 22301 Business continuity management systems standard}

Legal and operating requirements and business objectives make it necessary to implement at the airports Business Continuity Management System - BCMS based on ISO 22301 standard [10]. 
The concept of method for determining the minimum level of airport business continuity Koncepcja metody wyznaczania minimalnego poziomu ciaglości działania portu lotniczego

BCMS is a holistic management process that identifies potential threats to an organization and the impacts to business operations those threats, if realized, might cause, and which provides a framework for building organizational resilience with the capability of an effective response that safeguards the interests of its key stakeholders, reputation, brand and value-creating activities [10].

At airports BCMS is an important component of crisis management procedures $[1,11]$.

Business continuity management is defined as a holistic management process that identifies potential threats to an organization and the impacts to business operations those threats, if realized, might cause, and which provides a framework for building organizational resilience with the capability of an effective response that safeguards the interests of its key stakeholders, reputation, brand and valuecreating activities [10]. The key components and requirements of BCMS are:

- business continuity strategy;

- identification of critical business functions and processes;

- identification of critical resources;

- business continuity policy (intentions and direction of an organization as formally expressed by its top management);

- risk assessment - RA [10,3];

- risk management framework [16];

- business impact analysis - BIA (process of analyzing activities and the effect that a business disruption might have upon them) and risk assessment (overall process of risk identification, risk analysis and risk evaluation) $[10,6]$;

- business continuity plan (documented procedures that guide organizations to respond, recover, resume, and restore to a pre-defined level of operation following disruption);

- business continuity programme (ongoing management and governance process supported by top management and appropriately resourced to implement and maintain business continuity management);

- resources (all assets, people, skills, information, technology (including plant and equipment), premises, and supplies and information (whether electronic or not) that an organization has to have available to use, when needed, in order to operate and meet its objective).

BIA is conducted using the "cause-consequence" and "cost-benefit" analysis methods [6].

RA is conducted using the various methods, eg.: "what-if?", "matrix: resultprobability", "maintenance-oriented reliability" [6].

Based on the BIA and RA results are determined:

- recovery time objective - RTO (period of time following an incident within which product or service must be resumed, or activity must be resumed, or resources must be recovered);

- maximum tolerable period of disruption - MTPD (time it would take for adverse impacts, which might arise as a result of not providing a product/service or performing an activity, to become unacceptable); 
- maximum acceptable outage - MAO (time it would take for adverse impacts, which might arise as a result of not providing a product/service or performing an activity, to become unacceptable);

and minimum acceptable level of products and services - MALPS.

$R T O, M T P D, M A O$ and $M A L P S$ values are determined according to:

- legal objectives and requirements;

- business and operational objectives and requirements;

- established in business continuity plans lead times;

- costs and availability time of resources (and other assets).

It is recommended that in determining the plans incident management business continuity and values of: RTO, MTPD, MAO and MALPS take into account linkages with suppliers and cooperating entities, in terms of their so-called "Resistance operations" on interruption or disruption of business continuity and the possible scope and duration of their involvement in the implementation of the plans so-called "Integrated business continuity management" [11].

\section{The concept of the method for determining airport MALPS}

As demonstrated in previous studies [3, 4, 9] airport is a complex, continuous operation, renewable technical system reusable dynamic mixed (serial-parallel) reliability structure, whose continuity is determined by the operational state of the airport infrastructure elements, which can be described as a set - IPL:

$$
I P L=\left\{X_{P R N}, X_{L U N}, X_{\text {SIPax }}, X_{\text {SIBag }}, X_{\text {SISP }}, X_{S O}\right\}
$$

where:

$X_{P R N}$ - a subset of movement area elements [2],

$X_{L U N}$ - a subset of navigation aids [12],

$X_{S I P}$ - a subset of airport centralized infrastructure elements for passenger handling [12],

$X_{S I B}$ - a subset of airport centralized infrastructure elements for baggage and cargo handling [12],

$X_{S I S P}$ - a subset of airport centralized infrastructure elements for aircrafts handling and maintenance [12],

$X_{S O} \quad-$ a subset of security systems elements [12].

The result of occurrence an suitability event state of airport infrastructure elements will be the congestion and decrease the airport practical capacity $-C_{P}$ (Airport Practical Capacity is the number of operations (takeoffs and landings) that can be accommodated with no more than a given amount of delay, usually expressed in terms of maximum acceptable average delay [5]). The size of congestion (the losses of air traffic) depends on the size and duration of the incident lowering airport practical capacity.

The BCMS strategy sets objectives concerning:

- minimizing the risk of major interrupting incidents and preventive actions;

- ensuring business continuity on MALPS level;

- minimizing the resources restore time and restore to a required level of operation. 
The concept of method for determining the minimum level of airport business continuity Koncepcja metody wyznaczania minimalnego poziomu ciagtości działania portu lotniczego

As shown in [4], at the airport BCMS:

$$
R T O=M T P D=M A O=T_{A B}
$$

where:

$T_{A B}-$ acceptable time-out operation of the airport.

In practice, the MALPS level should be defined as the minimum acceptable airport practical capacity airport $-C_{P \min }$.

Taking into account the legal requirements, the practical value of $C_{P \min }$ should be determined for two cases :

- the occurrence of the interruption incident, as the result of an emergency situation $-C_{P \min A}$;

- the occurrence of the interruption incident, as the result of a crisis situation (any event that is, or is expected to lead to, an unstable and dangerous situation affecting an individual, group, community, or whole society) $-C_{P \operatorname{minK}}$.

Determine the value of $M A L P S_{A}=C_{P \min A}$ (due to the lack of specifications in the legislation) can be made by taking as the purpose of ensuring the continuity of operations of the airport for the average size of the supported traffic and air transport $-V R$, eg. in the scheduling season, and express the expected values for the distinguished subsystems of airport infrastructure, which designate within $T_{A B}$ minimum capacity for the $i$-th airport subsystem airport $-C_{P i m i n}$ :

$$
E_{i}\left(V R_{j}\right)=C_{i P \min }
$$

where:

$i \quad$ - subsystem of airport infrastructure: PRN, LUN, SIPax, SIBag, SISP, SO;

$j \quad-$ traffic object:

$S P$ - aircrafts,

Pax - passengers,

Bag - baggage and cargo.

Determine the value of $M A L P S_{K}=C_{P \min K}$ should be made in accordance with the legal requirements concerning critical infrastructure protection for each subsystems of airport infrastructure and servicing traffic objects.

Established values of $M A L S P_{i}$ determine, for each highlighted $i$-th airport subsystem airport, the value of gamma-percent resource, expressed by $-t_{\gamma}$ determining the amount of tasks (air traffic, passenger, baggage and cargo servicing and handling) which can be done with probability $-\gamma \cdot 100 \%$ [14]:

$$
P\left(T \geq t_{\gamma}\right)=\frac{\gamma}{100}
$$

In airport BCMS it is assumed that:

$$
\begin{aligned}
\frac{\gamma}{100} & \geq \frac{C_{P \min }}{C_{P}} \cdot 100 \% \\
t_{\gamma} & \geq T_{A B}
\end{aligned}
$$




$$
R_{i}\left(t_{\gamma i}\right)=\gamma_{i}
$$

Each $i$-th of highlighted airport infrastructure subsystem, has a very large number of elements and the high complexity of functional connections, as well as the very high reliability of individual elements. It is an important issue which concerns the determination of the form and parameters function of reliability $-R(t)$ [4].

Take into account the complexity of the reliability structure of airport and that in the event of any incident, preservation the MALPS level is determined by the serial reliability structure [3] assumes that the reliability function $-R(t)$ is expressed by the Weibulle distribution:

where:

$$
R(t)=\exp \left[-\lambda t^{k}\right]
$$

$\lambda$ - Weibulle distribution scale parameter;

$k$ - Weibulle distribution shape parameter; and therefore:

$$
t_{\gamma}=\left(\frac{1}{\lambda} \ln \frac{1}{\gamma}\right)^{\frac{1}{k}}
$$

Practical application of the presented concept will provide a rational basis for increasing the degree of efficiency and effectiveness of the airport BCMS, including reconfiguring the airport reliability structure and changing the airport maintenance program. To achieve this, it is necessary to have an appropriate set of real operational data of all highlighted subsystems and business continuity incidents (causes, course, effects, time, costs, losses). It shows that the RCM method should be used for data collecting and reporting and airport reliability management, taking into account the legal, environmental, social and economic aspects , as well as the diversity the "civilian" and "crisis" objectives [6].

\section{Summary and Conclusions}

Ensuring safety and continuity of operation of the airport is a legal obligation and operational and business purpose of the airport operator. Therefore, a common good practice is to implement a BCMS at airports. However, the complexity of the airport systems is causing difficulties in ensuring the efficiency and effectiveness of airport business continuity management. Therefore, the issue of airport business continuity managing should be considered multifaceted, taking into account the requirements of the legislation, as well as the conditions of operational, technical and economic, and seek adequate methods. The answer to these needs is the concept used in airport BCMS gamma-percent resources measure, as a measure of reliability and methods of RCM, among others, to perform risk assessment and improvement effective airport infrastructure maintenance, which will be the subject of further work of the author. 
The concept of method for determining the minimum level of airport business continuity Koncepcja metody wyznaczania minimalnego poziomu ciaglości działania portu lotniczego

\section{References}

[1] ACI World Facilitation and Services Standing Committee best practice paper: business continuity management framework and case studies for health-related disruptions at airports, ACI World Secretariat, 2012.

[2] Annex 14 ICAO Aerodromes, Vol 1 Aerodrome Design and Operations.

[3] Kozłowski M.: Zastosowanie metody minimalnych ścieżek zdatności w systemie BCMS w porcie lotniczym, Prace Naukowe Politechniki Warszawskiej - Transport, z. 100, Warszawa 2013, str. 121-130.

[4] Kozłowski M.: Aspect of reliability in airport business continuity management, Journal of KONBiN, nr 3(35)2015.

[5] Malarski M.: Inżynieria Ruchu Lotniczego, OWPW, Warszawa 2006.

[6] Risk management - Risk assessment techniques, norma ISO/IEC 31010:2009.

[7] Rozporządzenie Rady Ministrów z dnia 30 kwietnia 2010 r. w sprawie narodowego programu infrastruktury krytycznej, Dz. U. z 2010 r., Nr 83, poz. 541.

[8] Rozporządzenie Rady Ministrów z dnia 30 kwietnia 2010 r. w sprawie planów ochrony infrastruktury krytycznej, Dz. U. z 2010 r., Nr 83, poz. 542.

[9] Skorupski J., Kozłowski M., Stelmach A.: Metoda badania przepustowości portu lotniczego w warunkach zakłóceń, Problemy Niezawodności Systemów / Praca Zbiorowa, 2007, Polska Akademia Nauk, str. 288-298.

[10] Societal security - Business Continuity Management Systems Requirements, ISO 22301:2012.

[11] Transportation Research Board of the National Academies (Sponsored by the Federal Aviation Administration): Operational and Business Continuity Planning for Prolonged Airport Disruptions, ACRP Report 93, Washington D.C. 2013.

[12] Ustawa z dnia 3 lipca 2002 r. Prawo lotnicze, Dz. U. z 2013 r., poz. 1393.

[13] Ustawa z dnia 26 kwietnia 2007 r. o zarządzaniu kryzysowym, Dz. U. z 2007 r., $\mathrm{Nr}$ 89, poz. 590 (z późn. zm.).

[14] Ważyńska-Fiok K., Borgoń J., Jaźwiński J., Sikorski M.: Niezawodność statków powietrznych, ITWL, Warszawa 1992.

[15] Safety Management Manual (SMM), ICAO Doc 9859.

[16] Risk management - Principles and guidelines, ISO 31000.

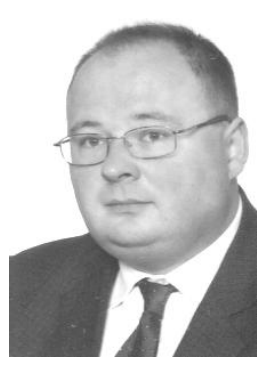

Michat Koztowski - Assistant Professor in the Department of Air Transport Engineering at Warsaw University of Technology, Faculty of Transport. Extensive experience in airport managing, gained from over twenty years of work in the operating area of Warsaw Chopin Airport. Author of numerous studies, publications and implementations in the field of safety, quality, reliability and capacity. (Share: 100\%). 


\section{KONCEPCJA METODY WYZNACZANIA MINIMALNEGO POZIOMU CIĄGLOŚCI DZIALANIA PORTU LOTNICZEGO}

\section{Wstęp}

Celem eksploatacji portu lotniczego jest obsługa operacji statków powietrznych $\mathrm{w}$ ruchu lotniskowym oraz handlowego przewozu lotniczego. Na procesy eksploatacji portu lotniczego składają się procesy związane z:

- operacjami (startów i lądowań) statków powietrznych w ruchu lotniskowym;

- obsługą naziemną statków powietrznych;

- obsługą naziemną przewozu lotniczego (pasażerów i ich bagażu, ładunków i poczty);

- utrzymaniem elementów infrastruktury (pola ruchu naziemnego, lotniczych urządzeń nawigacyjnych - tzw. „pomocy nawigacyjnych”, scentralizowanej infrastruktury - przeznaczonej do wykonywania obsługi naziemnej, systemów teleinformatycznych);

- zapewnieniem bezpieczeństwa, ochrony przed aktami bezprawnej ingerencji i porządku publicznego.

Przebieg realizacji tych procesów (a tym samym ich wyniki) podlega zakłóceniom przez oddziaływanie licznych (najczęściej losowych) czynników, do źródeł których należą w szczególności: środowisko naturalne (w tym meteorologiczne warunki wykonywania lotów), zawodność elementów infrastruktury, czynnik ludzki (intencjonalny i nieintencjonalny), zakłócenia przepływu ruchu lotniczego (np.: spiętrzenia, opóźnienia, przekierowania lotów), zdarzenia losowe (np. zakłócenia i ograniczenia w funkcjonowaniu układów komunikacyjnych) w otoczeniu portu lotniczego.

Przepisy prawne [12] nakładają na wszystkie podmioty (zarządzający portami lotniczymi, przewoźnicy lotniczy, agenci obsługi naziemnej, organy zarządzania ruchem lotniczym) i służby państwowe (straż graniczna, policja, urząd celny) priorytetowe obowiązki zapewnienia bezpieczeństwa oraz ciągłości i regularności obsługi ruchu i przewozu lotniczego. Prawnie określone cele dotyczące bezpieczeństwa osiągane są $\mathrm{w}$ szczególności poprzez ciągłe utrzymywanie zgodności ze specyfikacjami prawnymi $[2,3]$ oraz wdrażanie wymaganego prawnie [15] Systemu Zarządzania Bezpieczeństwem (ang. Safety Management System - SMS). Cele dotyczące ciągłości eksploatacji osiągane są w szczególności poprzez ustanawianie adekwatnych procedur i zasad organizacyjnych, jak również wdrażanie Systemu Zarządzania Ciągłością Działania (ang. Business Continuity Management System - BCMS) [10].

\section{Zagadnienie ciągłości działania portu lotniczego}

Norma [10] definiuje pojęcie ciągłości działania (ang. business continuity), jako zdolność organizacji (podmiotu) do kontynuacji dostarczania swoich wyrobów i świadczenia usług na akceptowalnych, zdefiniowanych poziomach po wystąpieniu incydentu zakłócającego działanie. 
The concept of method for determining the minimum level of airport business continuity Koncepcja metody wyznaczania minimalnego poziomu ciaglości działania portu lotniczego

Z przytoczonej definicji wynika, że zagadnienie ciągłości eksploatacji portu lotniczego należy rozważać w aspektach:

- celów i wymagań eksploatacji portu lotniczego;

- wielkości obsługiwanego ruchu i przewozu lotniczego;

- zdarzeń zakłócających lub przerywających ciągłość realizacji procesów eksploatacji portu lotniczego.

W odniesieniu do celów i wymagań dotyczących eksploatacji portu lotniczego, oprócz wymienionych powyżej - dotyczących zapewnienia bezpieczeństwa oraz ciągłości i regularności obsługi ruchu i przewozu lotniczego, należy mieć na uwadze aspekt przynależności infrastruktury portu lotniczego do infrastruktury krytycznej (def. systemy oraz wchodzące $\mathrm{w}$ ich skład powiązane ze sobą funkcjonalnie obiekty, w tym obiekty budowlane, urządzenia, instalacje, usługi kluczowe dla bezpieczeństwa państwa i jego obywateli oraz służące zapewnieniu sprawnego funkcjonowania organów administracji publicznej, a także instytucji i przedsiębiorców (...). [13]). Wynikają z tego określone wymagania i obowiązki prawne $[7,8,13]$ dotyczące ochrony infrastruktury krytycznej (def. wszelkie działania zmierzające do zapewnienia funkcjonalności, ciągłości działań i integralności infrastruktury krytycznej w celu zapobiegania zagrożeniom, ryzykom lub słabym punktom oraz ograniczenia i neutralizacji ich skutków oraz szybkiego odtworzenia tej infrastruktury na wypadek awarii, ataków oraz innych zdarzeń zakłócających jej prawidłowe funkcjonowanie. [13]). Jednym z obowiązków w tym zakresie jest opracowanie i utrzymywanie gotowości do realizacji Programu Ochrony Infrastruktury Krytycznej, w zakresie którego określa się [7], m.in.:

- cele i priorytety;

- warunki zapewniające doskonalenie ochrony i ciągłosci funkcjonowania infrastruktury krytycznej;

- sposoby postępowania w przypadku wystąpienia sytuacji kryzysowych, będących skutkiem zniszczenia lub zakłócenia funkcjonowania infrastruktury krytycznej, lub które niekorzystnie wpłynąć na tę infrastrukturę;

- sposoby postępowania w celu odtworzenia infrastruktury krytycznej;

z uwzględnieniem:

- wyników identyfikacji zagrożeń i potrzeby podniesienia poziomu ochrony infrastruktury krytycznej;

- prognozowanego lub stwierdzonego zwiększenia zapotrzebowania na usługi lub produkty będące przedmiotem działalności operatora infrastruktury krytycznej;

- przewidywanych lub stwierdzonych przerw lub zakłóceń ciągłości w dostawach usług lub produktów będących przedmiotem działalności operatora infrastruktury krytycznej;

- konieczności wsparcia działań podejmowanych przez operatora infrastruktury krytycznej w zakresie realizacji Programu.

Zgodnie z wymaganiami prawnymi [8] Program Ochrony Infrastruktury

Krytycznej musi określać trzy warianty postępowania, tj.:

- działanie w sytuacji zagrożenia lub zakłócenia funkcjonowania infrastruktury krytycznej;

- zapewnienie ciągłości funkcjonowania infrastruktury krytycznej;

- odtwarzanie infrastruktury krytycznej. 
Innym, szczególnym wymaganiem [2] w zakresie zapewnienia ciągłości działania portu lotniczego jest opracowanie planu i utrzymywanie gotowości do przyjęcia i zapewnienia obsługi wzmożonego, nieplanowanego ruchu lotniczego, $\mathrm{w}$ przypadku awaryjnego przekierowania ruchu lotniczego $\mathrm{z}$ innych lotnisk (w następstwie, np.: wystąpienia niekorzystnych warunków meteorologicznych, zaistnienia aktu bezprawnej ingerencji lub innych sytuacji kryzysowych) lub konieczności zamknięcia (lub ograniczenia pojemności) przestrzeni powietrznej dla ruchu lotniczego (w następstwie, np.: erupcji wulkanu lub zakłócenia przepływu ruchu lotniczego).

Zagadnienia wielkości obsługiwanego ruchu i przewozu lotniczego należy rozpatrywać z wykorzystaniem miar przepustowości portu lotniczego [5] oraz stopnia rzeczywistego wykorzystania dostępnej przepustowości portu lotniczego. $\mathrm{W}$ sensie mierzalnym przypadki przerwania lub obniżenia poziomu realizacji procesów eksploatacji portu lotniczego, będą wyrażane wielkością opóźnień operacji lotniczych oraz liczbą odwołanych lub przekierowanych lotów [9].

Incydenty zakłócające lub przerywające ciągłość realizacji procesów eksploatacji portu lotniczego mogą mieć różne przyczyny i prawdopodobieństwo występowania. Dla przedmiotu rozważań, szczególnie istotne są skutki i wielkość ich wpływu na poziom i ciągłość realizacji procesów eksploatacji portu lotniczego, z uwzględnieniem faktu, że skutki występujących zdarzeń mogą być dwojakiego rodzaju, tj.:

- obniżać przepustowość lub punktualność obsługi planowanego ruchu i przewozu lotniczego, np. na skutek wystąpienia awarii technicznej i ograniczenia wielkości dostępnych do użytku operacyjnego zasobów infrastruktury lub niekorzystnych meteorologicznych warunków wykonywania lotów (czyli występowania kongestii);

- powodować wystąpienie zapotrzebowania na obsługę ruchu i przewozu lotniczego większego, niż planowany, np. na skutek zamknięcia przestrzeni powietrznej dla ruchu lotniczego.

Innym, szczególnego rodzaju zagrożeniem, są zagrożenia epidemiczne, dla których porty lotnicze stanowią, tzw. „punkty wejścia” (ang. points of entry) i rozprzestrzeniania się chorób zakaźnych, jak również pierwszym punktem identyfikacji tych zagrożeń i przeciwdziałania im.

W każdym z wyróżnionych przypadków będą występowały opóźnienia i ograniczenia w obsłudze ruchu i przewozu lotniczego, które na zasadzie tzw. „efektu domina” będą mogły narastać i powiększać wielkość strat oraz będą mogły wywoływać kolejne, różnego rodzaju, zagrożenia.

\section{ISO 22301 - standard systemu zarządzania ciągłością dzialania}

Wymagania przepisów i specyfikacji prawnych, złożoność struktury niezawodnościowej i połączeń międzyprocesowych portu lotniczego, jak również uwarunkowania operacyjne i konkurencyjne na rynku przewozu lotniczego czynią koniecznym wdrażanie rozwiązań systemowych, których celem jest zapewnienie ciągłości eksploatacji portu lotniczego. Standardem takiego systemu jest międzynarodowa norma ISO 22301 [10], zgodnie z którą wdrażany jest BCMS (def. część ogólnego systemu zarządzania dotycząca ustanowienia, wdrożenia, funkcjonowania, monitorowania, przeglądu, utrzymania i doskonalenia ciągłości działania [10]) w coraz większej liczbie portów lotniczych. 
The concept of method for determining the minimum level of airport business continuity Koncepcja metody wyznaczania minimalnego poziomu ciaglości działania portu lotniczego

Praktyka ta wynika z określonych potrzeb, jak również z faktu, że BCMS jest istotnym komponentem procedur zarządzania kryzysowego $\mathrm{i}$ powszechnie zalecanym (lub wymaganym) do wdrożenia $[1,11]$.

Efektywne zapewnienie i skuteczne zarządzanie ciągłością działania (def. holistyczny proces zarządzania, identyfikujący potencjalne zagrożenia organizacji i skutki, jakie te zagrożenia mogą wywierać na działalność biznesową w przypadku ich wystąpienia, który zapewnia ramowe struktury budowania odporności organizacji i umożliwia skuteczną reakcję w celu ochrony interesów jej kluczowych interesariuszy, jej reputacji, marki i działalności kreujących wartość [10]) oparte jest na zasadzie ciaggłego doskonalenia i kluczowych komponentach:

- strategia zarządzania ciągłością działania, zgodnie z którą będzie wznawiana działalność i przywracana ciągłość operacyjna w przypadku wystąpienia incydentu, który może doprowadzić do zakłócenia (lub obniżenia poziomu) prowadzenia działalności, strat (ludzkich, informacji, finansowych i materialnych), sytuacji awaryjnej lub sytuacji kryzysowej;

- określenie procesów krytycznych, którym należy nadać priorytet po wystąpieniu incydentu, aby ograniczać jego negatywne skutki [10];

- ustalenie zasobów krytycznych, których brak, ograniczenie lub zablokowanie skutkuje przerwaniem (lub obniżeniem poniżej minimalnego poziomu akceptowalnego) realizacji procesów eksploatacji [10];

- plany zarządzania incydentami ciągłości działania, będące udokumentowanymi procedurami, których przedmiotem jest reagowanie, odtwarzanie, wznawianie i przywracanie funkcjonowania do ustalonego wcześniej poziomu po wystąpieniu zakłócenia lub incydentu (z wyróżnieniem: planów ciągłości działania i planów odtwarzania zasobów) [10];

- analiza wpływu na ciągłość działania (ang. Business Impact Analysis - BIA), będącej procesem analizy działalności oraz skutków, jakie zakłócenia mogą wywierać na te działalności $[10,6]$;

- ocena ryzyka (ang. Risk Assessment - RA), będącej całościowym procesem identyfikacji ryzyka, analizy ryzyka oraz ewaluacji ryzyka [10,3];

- struktura ramowa zarządzania ryzykiem ciągłości działania (ang. risk management framework), stanowiącej zestaw elementów zapewniających podstawy i ustalenia organizacyjne $\mathrm{w}$ zakresie projektowania, wdrażania, monitorowania, dokonywania przeglądów i ciągłego doskonalenia zarządzania ryzykiem [16].

BIA wykonywana jest $\mathrm{z}$ zastosowaniem metod analizy „przyczyna-skutek” (ang. cause-consequence analysis) i „koszt-korzyść” (ang. cost-benefit analysis) [6]. Do wykonania oceny RA stosowane są różne metody (najczęściej scenariuszowe), np.: „co-jeżeli?” (ang. structure „what-if?” - SWIFT), „macierzy: konsekwencjaprawdopodobieństwo" (ang. consequence-probability matrix), „utrzymanie zorientowane na niezawodność" (ang. reliability centred maintenance-RCM) [6].

Na podstawie wyników BIA i RA ustala się m.in.:

- docelowy czas wznowienia działania (ang. recovery time objective - RTO), tj. czas, w którym po zaistnieniu incydentu musi zostać w pełni przywrócona realizacja krytycznych procesów eksploatacji (lub dostępność zasobów i innych aktywów); 
- maksymalny tolerowany czas zakłócenia (ang. maximum tolerable period of disruption - MTPD), tj. czas, po którym niekorzystne skutki zaistnienia incydentu ciągłości stają się nieakceptowalne;

- maksymalny akceptowalny czas przestoju (ang. maximum acceptable outage - MAO), tj. czas do którego niekorzystne skutki zaistnienia incydentu ciągłości są akceptowane;

- minimalny akceptowalny poziom prowadzenia działalności (ang. minimum acceptable level of products and services - MALPS), który określa minimalny poziom działalności, który jest organizacja (podmiot) akceptuje dla osiągnięcia celów i spełnienia wymagań podczas zakłócenia, i który służy do wyznaczenia minimalnych wymaganych poziomów realizacji procesów krytycznych i utrzymywania zasobów krytycznych.

Wartości: $R T O, M T P D, M A O$ i $M A L P S$ ustala się z uwzględnieniem m.in.:

- celów i wymagań prawnych dotyczących działalności;

- celów i wymagań prawnych, biznesowych i umownych oraz operacyjnych, dotyczących realizacji poszczególnych procesów, z uwzględnieniem aspektów ekonomicznych;

- określonych czasów realizacji planów ciągłości działania i planów odtworzeniowych;

- kosztów i czasu dostępności zasobów (i innych aktywów).

Zalecane jest, aby przy ustalaniu planów zarządzania incydentami ciągłości działania oraz wartości: $R T O, M T P D, M A O$ i $M A L P S$ uwzględniać powiązania z dostawcami i podmiotami współpracującymi, w aspekcie ich tzw. „odporności operacyjnej" na zakłócenia ciągłości działania oraz możliwego zakresu i czasu ich zaangażowania $\mathrm{w}$ realizację planów - tzw. „zintegrowane zarządzanie ciągłością działania" [11].

\section{Koncepcja metody wyznaczania MALPS portu lotniczego}

Jak wykazano we wcześniejszych badaniach $[3,4,9]$ port lotniczy port lotniczy jest złożonym, pracującym w sposób ciągły, odnawialnym systemem technicznym wielokrotnego użytku o dynamicznej, mieszanej (szeregowo-równoległej) strukturze niezawodnościowej, którego ciągłość działania jest determinowana stanem zdatności eksploatacyjnej elementów infrastruktury portu lotniczego, którą można opisać zbiorem - IPL:

$$
I P L=\left\{X_{P R N}, X_{L U N}, X_{\text {SIPax }}, X_{\text {SIBag }}, X_{\text {SISP }}, X_{S O}\right\}
$$

gdzie:

$X_{P R N}$ - podzbiór elementów infrastruktury pola ruchu naziemnego [2],

$X_{L U N}$ - podzbiór lotniczych urządzeń naziemnych [12],

$X_{S I P}$ - podzbiór elementów scentralizowanej infrastruktury, przeznaczonych do obsługi naziemnej pasażerów [12],

$X_{S I B}$ - podzbiór elementów scentralizowanej infrastruktury, przeznaczonych do obsługi naziemnej bagażu i ładunków [12],

$X_{S I S P}$ - podzbiór elementów scentralizowanej infrastruktury, przeznaczonych do obsługi naziemnej statków powietrznych [12],

$X_{S O}$ - podzbiór elementów technicznych systemów ochrony przed aktami bezprawnej ingerencji (m.in. systemy kontroli bezpieczeństwa osób, bagażu i ładunków, kontroli dostępu) [12]. 
The concept of method for determining the minimum level of airport business continuity Koncepcja metody wyznaczania minimalnego poziomu ciaglości działania portu lotniczego

Wystąpienie stanu niezdatności elementów infrastruktury będzie skutkowało występowaniem kongestii i obniżeniem przepustowości praktycznej portu lotniczego $-C_{P}$ (def. liczba operacji, prowadzonych w ustalonych warunkach ruchu lotniczego i ciągłej obsłudze pasażerów, ładunków, towarów i poczty, startów i lądowań umownego statku powietrznego w jednostce czasu, dla której, średni czas opóźnienia będzie odpowiadał akceptowalnemu średniemu czasowi opóźnienia [5]). Wielkość strat ruchu zależy od wielkości i czasu trwania incydentu obniżającego przepustowość praktyczną portu lotniczego.

W zakresie strategii BCMS ustala się w szczególności cele dotyczące:

- minimalizacji ryzyka wystąpienia incydentów przerwania ciągłości działania działania zapobiegawcze;

- zapewnienia ciągłości działania na poziomie $M A L P S$, w przypadku wystąpienia incydentu przerwania ciągłości działania;

- minimalizacji czasu odtwarzania zasobów i przywrócenia pełnej ciągłości działania.

Jak wykazano w [4], w BCMS portu lotniczego:

$$
R T O=M T P D=M A O=T_{A B}
$$

gdzie:

$T_{A B}$ - akceptowalny czas przerwy eksploatacji portu lotniczego.

W praktyce zarządzania eksploatację portu lotniczego, poziom MALPS należy zdefiniować jako minimalną akceptowalną przepustowość praktyczną portu lotniczego $-C_{P \min }$. Uwzględniając wymagania przepisów prawnych, określenia wartości $C_{P \min }$ należy dokonać dla dwóch przypadków:

- wystąpienia incydentu przerwania ciągłości działania, jako zdarzenia awaryjnego $-C_{P \min A}$;

- wystąpienia incydentu przerwania ciągłości działania, jako sytuacji kryzysowej (def. sytuacja wpływająca negatywnie na poziom bezpieczeństwa ludzi, mienia w znacznych rozmiarach lub środowiska, wywołującą znaczne ograniczenia w działaniu właściwych organów administracji publicznej ze względu na nieadekwatność posiadanych sił i środków) $-C_{P \operatorname{minK} K}$.

Ustalenia wartości $M A L P S_{A}=C_{P \min A}$ (z uwagi na brak specyfikacji w przepisach prawnych) można dokonać przyjmując jako cel zapewnienie ciągłości działania portu lotniczego dla przeciętnych wielkości obsługiwanego ruchu i przewozu lotniczego - VR, np. w sezonie rozkładowym i wyrazić wartościami oczekiwanymi dla wyróżnionych podsystemów infrastruktury portu lotniczego i obsługiwanych obiektów ruchu, wyznaczającymi wymaganą do utrzymania przez czas przywracania pełnej ciągłości działania $-T_{A B}$ minimalną przepustowość $i$-tego podsystemu portu lotniczego $-C_{P i \text { min }}$ :

$$
E_{i}\left(V R_{j}\right)=C_{i P \min }
$$

gdzie:

$i \quad$ - podsystem infrastruktury portu lotniczego: PRN, LUN, SIPax, SIBag, SISP, SO; 
$j \quad-$ obiekt ruchu:

$S P$ - statki powietrzne,

$P a x$ - pasażerowie,

$B a g$ - bagaże i ładunki.

Ustalenia wartości $M A L P S_{K}=C_{P \min K}$ należy dokonać zgodnie z ustalonymi celami w zakresie ochrony infrastruktury krytycznej dla poszczególnych podsystemów infrastruktury portu lotniczego i obsługiwanych obiektów ruchu.

Ustalone wartości $M A L S P_{i}$ w sensie teorii niezawodności systemów technicznych [14], wyznaczają dla każdego wyróżnionego $i$-tego podsystemu portu lotniczego gammaprocentowy zasób pracy, tzw. „zapas zdatności”, wyrażany czasem $-t_{\gamma}$ opisującym ilość pracy, jaka z prawdopodobieństwem $-\gamma \cdot 100 \%$ może zostać wykonana:

$$
P\left(T \geq t_{\gamma}\right)=\frac{\gamma}{100}
$$

W zakresie BCMS portu lotniczego należy ogólnie przyjąć, że:

$$
\begin{aligned}
& \frac{\gamma}{100} \geq \frac{C_{P \min }}{C_{P}} \cdot 100 \% \\
& t_{\gamma} \geq T_{A B}
\end{aligned}
$$

Gamma-procentowy zasób pracy każdego wyróżnionego $i$-tego podsystemu portu lotniczego będzie zależny od niezawodności tego podsystemu $-R_{i}(t)$ :

$$
R_{i}\left(t_{i j}\right)=\gamma_{i}
$$

Każdy z wyróżnionych podsystemów portu lotniczego charakteryzuje się bardzo dużą liczbą elementów i wysoką złożonością powiązań funkcjonalnych, jak również bardzo wysoką niezawodnością poszczególnych elementów, co stanowi istotne zagadnienie problemowe przy określaniu postaci i parametrów funkcji niezawodności - $R(t)$ [4]. Biorąc pod uwagę złożoność struktury niezawodnościowej i to, że w przypadku zaistnienia incydentu ciągłości działania, utrzymanie MALPS determinowane jest przez szeregowe struktury niezawodnościowe [3] przyjęto założenie, że funkcja niezawodności $-R(t)$ wyrażona jest rozkładem Weibulle'a:

$$
R(t)=\exp \left[-\lambda t^{k}\right]
$$

gdzie:

$\lambda$ - parametr skali rozkładu Weibulle'a;

$k$ - parametr kształtu rozkładu Weibulle'a.

w związku z czym, gamma-procentowy zasób pracy będzie wyrażony zależnością: 
The concept of method for determining the minimum level of airport business continuity Koncepcja metody wyznaczania minimalnego poziomu ciaglości działania portu lotniczego

$$
t_{\gamma}=\left(\frac{1}{\lambda} \ln \frac{1}{\gamma}\right)^{\frac{1}{k}}
$$

Praktyczne zastosowanie przedstawionej koncepcji będzie stanowiło podstawę racjonalnego zwiększenia stopnia skuteczności i efektywności zapewnienia ciągłości działania portu lotniczego, m.in. poprzez rekonfigurację struktury niezawodnościowej i zmiany programów obsługowych. Dla osiągnięcia tego, konieczne jest jednak dysponowanie odpowiednim zbiorem rzeczywistych danych o przebiegach eksploatacyjnych wszystkich podsystemów oraz zaistniałych incydentach ciągłości działania (przyczyny, przebieg, skutki, czas, koszty, straty). Wskazuje to na celowość zastosowania systemowych metod RCM, której zakres stosowania rozpoczyna się od systemu raportowania, a kończy na określeniu zasad zarządzania niezawodnością $\mathrm{w}$ procesach utrzymania technicznego, z uwzględnieniem aspektów prawnych, środowiskowych, społecznych i ekonomicznych, jak również zróżnicowania celów „cywilnych” i ,kryzysowych” [6].

\section{Podsumowanie i wnioski}

Zapewnienie ciągłości eksploatacji portu lotniczego jest, na równi z zapewnieniem bezpieczeństwa, podstawowym obowiązkiem podmiotu zarządzającego portem lotniczym, w odniesieniu do czego powszechną dobrą praktyką staje się wdrażanie BCMS w portach lotniczych. Jednak złożoność systemu jakim jest port lotniczy powoduje trudności w faktycznym skutecznym i faktycznym zapewnieniu ciągłości eksploatacji. W związku z tym zagadnienie ciągłości eksploatacji portu lotniczego można (i należy) rozpatrywać wieloaspektowo, z uwzględnieniem wymagań wynikających z przepisów prawnych, jak również uwarunkowań operacyjnych, technicznych i ekonomicznych oraz poszukiwać odpowiednio skutecznych metod. Odpowiedzią na te potrzeby jest przedstawiona koncepcja zastosowania w BCMS portu lotniczego gamma-procentowego zasobu pracy jako miary niezawodności oraz metod RCM m.in. do wykonywania oceny ryzyka i doskonalenia programów obsługowych elementów infrastruktury portu lotniczego, co będzie przedmiotem dalszych prac autora.

\section{Literatura}

[1] ACI World Facilitation and Services Standing Committee best practice paper: business continuity management framework and case studies for health-related disruptions at airports, ACI World Secretariat, 2012.

[2] Aneks 14 ICAO: Lotniska, Tom I. - Projektowanie i eksploatacja lotnisk, Dz. Urz. ULC z 2011 r. Nr 4, poz.4.

[3] Kozłowski M.: Zastosowanie metody minimalnych ścieżek zdatności w systemie BCMS w porcie lotniczym, Prace Naukowe Politechniki Warszawskiej - Transport, z. 100, Warszawa 2013, str. 121-130. 
[4] Kozłowski M.: Aspect of reliability in airport business continuity management, Journal of KONBiN, nr 3(35)2015.

[5] Malarski M.: Inżynieria Ruchu Lotniczego, OWPW, Warszawa 2006.

[6] Risk management - Risk assessment techniques, norma ISO/IEC 31010:2009.

[7] Rozporządzenie Rady Ministrów z dnia 30 kwietnia 2010 r. w sprawie narodowego programu infrastruktury krytycznej, Dz. U. z 2010 r., Nr 83, poz. 541.

[8] Rozporządzenie Rady Ministrów z dnia 30 kwietnia 2010 r. w sprawie planów ochrony infrastruktury krytycznej, Dz. U. z 2010 r., Nr 83, poz. 542.

[9] Skorupski J., Kozłowski M., Stelmach A.: Metoda badania przepustowości portu lotniczego w warunkach zakłóceń, Problemy Niezawodności Systemów / Praca Zbiorowa, 2007, Polska Akademia Nauk, str. 288-298.

[10] Societal security - Business Continuity Management Systems Requirements, norma ISO 22301:2012.

[11] Transportation Research Board of the National Academies (Sponsored by the Federal Aviation Administration): Operational and Business Continuity Planning for Prolonged Airport Disruptions, ACRP Report 93, Washington D.C. 2013.

[12] Ustawa z dnia 3 lipca 2002 r. Prawo lotnicze, Dz. U. z 2013 r., poz. 1393.

[13] Ustawa z dnia 26 kwietnia 2007 r. o zarządzaniu kryzysowym, Dz. U. z 2007 r., Nr 89, poz. 590 (z późn. zm.).

[14] Ważyńska-Fiok K., Borgoń J., Jaźwiński J., Sikorski M.: Niezawodność statków powietrznych, ITWL, Warszawa 1992.

[15] Zarządzanie Bezpieczeństwem, Podręcznik ICAO Doc 9859 AN/474, Dz. Urz. ULC z 2011 r. Nr 15, poz. 94.

[16] Zarządzanie Ryzykiem - Zasady i Wytyczne, norma PN-ISO 31000:2012.

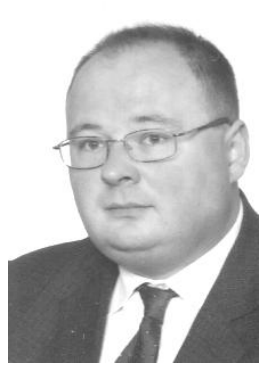

Michal Kozlowski - Adiunkt w Zakładzie Inżynierii Transportu Lotniczego Wydziatu Transportu Politechniki Warszawskiej. Bogate doświadczenie w zakresie zarzadzania portem lotniczym, wyniesione $z$ ponad dwudziestoletniej pracy zawodowej $w$ obszarze operacyjnym Lotniska Chopina w Warszawie. Autor licznych badań, publikacji $i$ wdrożeń, m.in. z zakresu systemów zarzadzania, $w$ tym bezpieczeństwem, ciagłościa działania, ryzykiem i przepustowościa. (Udział 100\%). 
The concept of method for determining the minimum level of airport business continuity Koncepcja metody wyznaczania minimalnego poziomu ciagtości działania portu lotniczego 